\title{
PERANAN TRADISI NGUSONG BARANG DALAM PEMBENTUKAN KELUARGA SAKINAH PADA MASYARAKAT OKI PALEMBANG
}

\author{
Akmal Alkautsar \\ Fakultas Syariah UIN MALIKI Malang \\ Telepon: 081260609206 \\ Email:Akma_alkautsar@yahoo.co.id
}

\begin{abstract}
Abstrak
Persoalan tradisi dalam perkawinan tidak diatur dalam al Qur'an dan al Hadis secara terperinci sehingga kriteria dan teknik operasionalnya berbeda-beda dalam masyarakat seperti tradisi Ngusong Barang pada masyarakat Kayu Agung. sebuah tradisi prosesi barang bawaan sebagai timbal balik dari pemberian mahar pada saat perkawinan yang bertujuan untuk mewujudkan keluarga sakinah. Tujuan penelitian ini adalah untuk mendeskripsikan pandangan masyarakat tentang tradisi Ngusong Barang dan juga untuk mendeskripsikan hubungannya dalam pembentukan keluarga sakinah. Penelitian ini menggunakan metode penelitian sosiologis fenemenologis dan pendekatan deskriptif. Hasil penelitian menunjukkan bahwa tradisi Ngusong Barang mempunyai arti yang sangat penting dan mempunyai makna baik secara filosofis sebagai lambang eratnya hubungan tali silaturrahim dan sesuatu yang dapat mengangkat martabat seseoarang, besan, dan kalangan masyarakat adat Morge Siwe.
\end{abstract}

Qoran and hadith do not regulate marriage tradition in detail as its criteria and operational technique may be implemented differently such as Ngusong Barang tradition in kayu Agung Society. It is a tradition of bringing some marriage gift process as the changing dowry of marriage in order to build harmonious family. The objective of this research is to describe society's perception on Ngusong Barang tradition and its reationship with harmonious family. This research uses fphenomenologycal and sociological method as well as descriftive approach. The result shows that the tradition of bringing marriage gift has significant meaning philosophically as the symbol of tied relationship and it can rise the dignity of parents in-law including Morge Siwe society.

Kata kunci: keluarga sakinah, ngusong barang, barang bawaan

Tiap masyarakat memiliki budaya berbeda dan tiap budaya tentu ada masyarakatnya, karena keduanya dwi tunggal, dua di antara yang satu dari tunggal membentuk sosial budaya masyarakat.[1] Budaya atau kebudayaan merupakan tata cara melakukan dan hasil kelakuan masyarakat, sedangkan masyarakat merupakan tempat manusia melakukan tindakan atau perbuatan-perbuatan. Oleh karena itu, perbuatan atau prilaku masyarakat tersebut tidak lepas dari sebuah aturan atau norma yang berlaku di dalam masyarakat itu sendiri.

Setiap daerah memiliki keunikan kreasi dan budaya yang mengkristal menjadi sebuah tradisi, salah satu tradisi khusus yang masih sering dipraktekan di Indonesia adalah perkawinan adat. Hal ini yang terjadi di kalangan masyarakat Kayu Agung OKI Palembang yang masih kental memegang tradisi dalam hal proses pernikahan.

Dalam sistem perkawinan mabang handak masyarakat Kayu Agung ada sebuah tradisi yang wajib dijalankan ketika melangsungkan pernikahan yakni tradisi ngusong barang atau yang dalam ba-

\footnotetext{
[1]Wahyu Ms, Wawasan Ilmu Sosial Dasar (Surabaya : Usaha Nasional, 1986), 61.
} 
hasa asli masyarakat setempat disebut dengan istilah ngatot san-san yakni sebuah tradisi sebagai timbal balik dari kesepakatan mahar yang ditetapkan dalam masa pertunangan[2]. Tradisi ini sudah turun temurun dilaksanakan dan menjadi sebuah kewajiban yang tidak bisa ditinggalkan dalam proses perkawinan.

Ngusong barang atau ngatot san-san adalah harta bawaan yang dibawa oleh mempelai perempuan, harta ini bisa berbentuk barang pecah belah maupun perabotan rumah tangga, barang-barang tersebut diperoleh baik dari orang tuanya sebagai lambang warisan dan juga pemberian dari sanak keluarga sebagai sebuah ikatan kekeluargaan yang sangat erat[3]

Sedangkan mahar yang lebih dikenal di kalangan masyarakat di sebut maskawin merupakan pemberian sejumlah harta oleh keluarga pengantin putra kepada pihak keluarga penganten putri. Kebiasaan masyarakat dalam pemberian maskawin sangatlah beragam wujud dan jumlahnya, mulai dari berwujud barang mewah sampai yang sederhana. Pada dasarnya pemberian maskawin bukanlah ditujukan untuk mempersulit seseorang dalam melakukan pernikahan akan tetapi maskawin merupakan pemberian sesuatu dari seorang laki-laki kepada istrinya sebagai kewajiban yang disertai sikap kerelaan dan didasarkan pada azas kepatutan atau kelayakan sehingga akhirnya tercipta dari pernikahan tersebut sebuah keluarga yang sakinah, karena pada dasarnya keluarga sakinah terbangun atas dua dimensi yaitu dimensi kualitas hidup dan dimensi waktu, durasi, atau stabilitas yang semua itu tercipta dari sebuah bangunan dasar pernikahan[4].

Berdasarkan latar belakang permasalahan sebagaimana yang telah dipaparkan di atas dapat

[2]Ahmad Bakri, Interview (Kayu Agung, 21 April 2007).

[3] Hasil wawancara dengan $\mathrm{H}$. Tarmizi (Kayu Agung 29 April 2007).

[4]Jaih Mubarok, Modernisasi Hukum Perkawinan di Indonesia (Bandung: Pustaka Bani Quraisy, 2005), 15-17. diindentifikasikan dua pokok permasalahan yang menjadi fokus bahasan pada penelitian ini yaitu makna tradisi ngusong barang bagi masyarakat Kayu Agung sendiri serta peran tradisi tersebut terhadap pembentukan keluarga sakinah.

Dalam membincang topik diatas terkait dengan tujuan dilaksanakannya, maka penting untuk mendiskusikan konsep keluarga sakinah. Keluarga sakinah yang didalamnya termasuk juga mawaddah wa rahmah berasal dari dua kata yaitu keluarga dan sakinah. Keluarga berasal dari kata kawula dan warga, sebagai kawula di lingkungan warga ia harus mengabdikan segenap kemampuan untuk keluarganya. Sebaliknya warga, ia mempunyai hak untuk ikut mengurus dan mendidik segenap kebutuhan di lingkungan keluarganya.[5] Keluarga didefinisikan sebagai masyarakat terkecil sekurangkurangnya terdiri dari pasangan suami istri sebagai inti dan berikut anak-anak yang lahir dari mereka.

Sakinah berasal dari susunan kata sakana yaskunu sakinatan yang berarti rasa tentram dan damai. Sakinah yang bermula dari akar kata sakana berarti tenang, damai, hening, tinggal. Kata $s a$ kinah diartikan oleh Cyril Glasse dengan ketenangan, kedamaian.[6] Dalam Islam kata sakinah menandakan ketenangan dan kedamaian secara khusus yakni kedamaian dari Allah yang berada dalam kalbu, sebagaimana disebutkan dalam firman Allah:[7]

uqèd ül\%\%@! $\%$ tAtRr\& spoYÅ3ij\$\# Îu

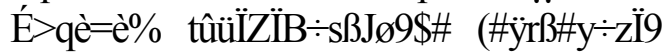
\$YZ»yĴ) yï̈B öNÍkÈ]»yĴ̃) 3 ᄀ!ur ßqãZã ÏNouq»yJ $i i 9 \#$ ÇÜöF $\left\{\$ \#\right.$ ur 4 tb\%x.ur ${ }^{a}$ !\$\# \$, Ĵ̃=tã \$VJÅ3ym ÇÍlE

Dia-lah yang telah menurunkan ketenangan ke dalam hati orangorang mukmin supaya keimanan mereka bertambah di samping keimanan mereka (yang telah ada).

[5]Asrofi, M. Thohir, Keluarga Sakinah Dalam Tradisi Islam Jawa (Yogyakarta: Arindo Nusa Media, 2006), 1-2.

[6]Asrofi, M. Thohir, Keluarga Sakinah, 2.

[7]QS. al-Fath (48) : 4. 


\section{dan kepunyaan Allah-lah tentara langit dan bumi dan adalah Allah Maha mengetahui lagi Maha Bi- jaksana."}

Sedangkan M. Quraish Shihab menjelaskan kata sakinah terdiri dari tiga huruf yaitu sin, kaf, dan nun. Semua kata yang dibentuk oleh ketiga huruf itu menggambarkan ketenangan setelah sebelumnya ada gejolak.[8] Kata sakinah menurut Shihab diambil dari akar kata sakana yang berarti diam atau tenangnya sesuatu setelah ada gejolak. Sakinah dalam berkeluarga adalah ketenangan yang dinamis dan aktif. Jadi, keluarga sakinah adalah keluarga yang mampu menciptakan suasana kehidupan berkeluarga yang tentram, dinamis dan aktif.

Sehubungan dengan hal untuk menggapai keluarga sakinah maka didalam hubungan keluarga harus ada kerjasama, timbal balik dan hidup yang serasi, selaras dan seimbang. Disamping itu juga rumah tangga sakinah juga mampu menjalin hubungan persaudaraan yang harmonis dengan sanak famili dan hidup rukun dalam bertetangga, bermasyarakat, dan bernega$\mathrm{ra}[9]$.

Tidak jauh berbeda dengan informasi yang disampaikan oleh $\mathrm{H}$. Tarmizi. Tradisi tersebut menurut A.Rahman Ahmad ketua Pembina adat Kayu Agung yang mengatakan bahwa tradisi tersebut mempunyai arti yang sangat penting sebagai lambang eratnya hubungan kekeluargaan diantara kerabat dekat marga Kayu Agung dan juga sebagai tanda warisan orang tuannya kepada anak perempuan mereka[10] Pada saat pelaksanaan tradisi tersebut ada sebagian masyarakat yang menganggap tradisi tersebut sebagai prosedur yang harus dilaksanakan tanpa mengerti makna yang terkandung dalam tradisi

[8]Asrofi, M. Thohir, Keluarga Sakinah, 3.

[9]Agus Musthofa, Poligami Yuuk!? Benarkah alqur'an menyuruh berpoligami karena alasan syahwat (Surabaya: Padma Press, 2007), 167.

[10]Hasil wawancara dengan A.Rahman Ahmad (Kayu Agung, 29 April 2007). tersebut seperti informasi yang peneliti peroleh dari beberapa pelaku tradisi tersebut yakni Sudarsan dan M. Ali yang mengatakan bahwa tradisi tersebut hanyalah simbol dari proses pelaksanaan sistem perkawinan adat.

Jika melihat dari penjelasan tadi dapat dikatakan bahwa sebuah tradisi, baik itu perkawinan, dan lain sebagainya merupakan sebuah warisan masa lalu yang masih dipertahankan hingga sekarang yang mempunyai nilai-nilai serta norma yang sangat mendalam pada diri dan jiwa masyarakat itu sendiri [11]

\section{METODE}

Penelitian ini menggunakan pendekatan deskriptif kualitatif sebagai prosedur penelitian yang menghasilkan data deskriptif yang berupa kata-kata tertulis dan bukan angka. Dalam penelitian ini, jenis penelitian yang digunakan adalah sosiologis atau empiris, karena dalam penelitian ini peneliti akan menggambarkan secara detail dan mendalam tentang suatu keadaan atau fenomena dari objek penelitian yang diteliti dengan cara mengembangkan konsep serta menghimpun kenyataan yang ada.

Untuk menghadapi berbagai masalah sosial yang muncul di dalam kehidupan masyarakat maka penelitian ini menggunakan paradigma fenomenologis, dimana paradigama ini digunakan pada penelitian kualitatif karena dalam penelitian ini mengarahkan peneliti untuk mengetahui bagaimana cara masuk ke dalam dunia konseptual para subjek yang akan diteliti dengan sedemikian rupa. Sehingga, dapat memahami kehidupan sehari hari khususnya saat berinteraksi dengan objek yang diteliti.

Data yang telah diperoleh kemudian diolah melalui beberapa tahapan, yakni:

Editing, dengan cara peneliti mengamati kembali data-data yang telah diperoleh dilapangan melalui wawancara dan observasi dan catatan

[11]Imam Bawani. Tradisonalisme Dalam Pendidikan Islam. (Surabaya: Al Ikhlas. 1990), 23. 
dilapangan pada saat penelitian kemudian memilah apakah data yang telah ada sudah cukup untuk keperluan analisis atau cukup yang berkaitan tentang peranan tradisi ngusong $b a$ rang dalam pembentukan keluarga sakinah.

Tahap selanjutnya adalah classifiying. Pada tahap ini peneliti mengklasifikasikan data yang diperoleh dilapangan dengan dua tingkatan yaitu, berhubungan dengan makna tradisi ngusong barang bagi masyarakat setempat, yang berhubungan dengan sejauh mana peranan tradisi tersebut dalam pembentukan keluarga sakinah.

Selanjutnya peneliti berusaha menguji kevaliditasan data yang telah ada dan diklasifikasikan menurut keperluan analisis kemudian data tersebut di Cross- check kembali agar menghasilkan data yang sempurna demi kegunaan analisis hasil penelitian dengan proses yang disebut dengan verifying.

Dalam penelitian ini peneliti akan mendekripsikan secara induktif permasalahan tradisi ngusung barang yang ada dalam sistem perkawinan masyarakat Kayu Agung dengan berupaya mengetahui sistem perlaksanaan tradisi tersebut, makna filosofis yang terkandung dalam tradisi tersebut kemudian dikaitkan dengan pembentukan suatu keluarga sehingga akan menimbulkan suatu kesimpulan secara umum bahwa ada tidaknya keterkaitan pelaksanaan tradisi $n g u-$ song barang dalam sistem perkawinan masyarakat setempat dengan pembentukan suatu keluarga yang sakinah.

\section{HASIL DAN PEMBAHASAN}

\section{Hasil}

Pada umumnya mayoritas masyarakat Kayu Agung beragama Islam dan tergolong masyarakat yang mempunyai kepedulian tinggi terhadap pendidikan. Terkait dengan tradisi, Marga Kayu Agung sangat memelihara tradisi terutama tentang sistem hukum adat yang berhubungan dengan perkawinan, tujuannya adalah melestarikan dan mengembangkan adat istiadat daerah mereka karena dengan memelihara tradisi tersebut menunjukan suatu sikap upaya untuk mem- pertahankan kesatuan suatu kelompok masyarakat dalam mengarungi era globalisasi. Dalam hal ini lebih diindentifikasikan dengan stagnasi yaitu suatu sikap yang bertabrakan dengan progress.[12]

Beberapa responden berpendapat bahwa perkawinan adat merupakan ciri khas budaya setempat yang mempunyai nilai-nilai yang sesuai dengan masyarakatnya. Mereka mengetahui tata upacara perkawinanan adat dan nilai-nilai simbolik di dalamnya karena dikenalkan oleh lingkungannya (orang tua, kakek nenek, saudara yang lain atau tetangga). Dari situ mereka mengenal apa yang namanya lamaran, pertunangan dan lain-lain. Juga cara bersikap dan bertindak (termasuk berdandan dan berpakaian, dilihat dari hubungan persaudaraannya dan lain-lain) apabila terlibat di dalamnya baik hanya sebagai tamu biasa, atau terlibat secara langsung (misal menjadi penerima tamu). Akan tetapi mereka hanya akan datang bila diundang oleh tuan rumah atau yang bersangkutan, karena datang tanpa diundang adalah aib. Diundang pun kalau ada hal lain yang lebih penting akan ijin tidak datang. Pada saat pelaksanaan tradisi tersebut ada sebagian masyarakat yang menganggap tradisi tersebut sebagai prosedur yang harus dilaksanakan tanpa mengerti makna yang terkandung dalam tradisi tersebut.

Upacara perkawinan tradisional tersebut akan tetap ada sepanjang hal tersebut dianggap masih berfungsi oleh masyarakat pendukungnya. Demikian pula dengan upacara perkawinan tradisional Kayu Agung. Agar upacara perkawinan tradisional tersebut tetap lestari perlu diadakan pembinaan-pembinaan baik formal maupun non formal, lebih-lebih pada generasi muda karena pengetahuan mereka tentang upacara perkawinan tradisional secara menyeluruh kurang.

Disisi lain, tradisi tersebut mengandung makna yang terselubung yakni tradisi tersebut mempunyai makna sebagai pengikat bagi para pasangan suami istri yang baru menikah karena dengan pelaksanaan tradisi tersebut sebagian masyarakat beranggapan bahwa hal itulah pengikat eratnya jalinan hubungan suami istri hal ini

[12]Imam Bawani. Tradisonalisme, 34-35. 
disebabkan jika dikemudian hari terjadi perceraian antara pasangan suami istri tersebut maka pihak suami harus mengembalikan semua barang bawaan yang dibawa oleh pihak istri ketika mereka melaksanakan pernikahan dulu.

Berdasarkan penjelasan makna tradisi ngusong barang dan proses pelaksaannya dapat ditarik suatu kesimpulan bahwa berlangsungnya suatu pernikahan dalam suatu masyarakat yang melibatkan berbagai bentuk dan rangkaian tradisi, hal ini berlangsung secara turun temurun dari waktu ke waktu, berbagai bentuk dan rangkaian budaya yang mengitari acara pelaksanaan perkawinan itu hidup dan terjaga di dalam kehidupan masyarakat.

Perkawinan menurut hukum adat tidak semata-mata berarti suatu ikatan antara seorang pria dan wanita sebagai suami istri untuk maksud mendapat keturunan dan membangun serta membina kehidupan keluarga, tetapi juga berarti suatu hubungan hukum yang menyangkut para anggota keluarga kerabat baik dari suami maupun dari istri.

Dari sejumlah rangkaian proses pelaksanaan sebuah tradisi terdapat simbol-simbol budaya yang melekat disana, simbol-simbol budaya tersebut memiliki makna yang universal, berpengaruh dan berkekuatan untuk membentuk pemahaman masyarakat, setelah mengakar proses tersebut akan melegalitas dan melembaga sebagai hal yang sah. Marsiyo mengindentifikasikan adanya tradisi-tradisi atau simbol-simbol budaya dalam pelaksanaan pernikahan yang bernilai negatif dan positif.

Upacara adat perkawinan tradisional sesungguhnya bukanlah sekadar pesta saja karena di dalamnya banyak pesan yang disampaikan melalui lambang atau simbol yang dipakai dalam sistem upacara adat tersebut. Pada umumnya pesan-pesan simbolik itu mengandung normanorma yang dilakukan oleh seseorang. Oleh karena itu apa yang dipesankan biasanya menjadi pegangan hidup dan diwariskan kepada anak cucu.[13]

[13]Hilman Hadikusuma, Hukum Perkawinan Adat dengan Adat istiadat dan upacara Adatnya.
Diantara nilai-nilai dari simbol-simbol yang berkonotasi positif dalam proses pelaksanaan tradisi ngusong barang dalam sistem perkawinan adat masyarakat Kayu Agung adalah tradisi tersebut melambangkan eratnya jalinan tali silaturrahim atau kekerabatan diantara sanak saudara dalam mempersiapkan dan membekali anggota keluarga yang hendak melangsungkan pernikahan. Dan juga tradisi ngusong barang tersebut melambangkan nilainilai yang menjunjung tinggi martabat seorang anak perempuan dalam hal ini barang bawaan yang dibawa oleh mempelai perempuan tersebut sebagai simbol warisan dari orang tuanya kepada anak perempuan karena anak perempuan dianggap nantinya yang menghidupi adalah suaminya.

Sedangkan nilai-nilai dari simbol-simbol yang berkonotasi negatif dalam proses pelaksanaan tradisi ngusong barang dalam proses pernikahan adat masyarakat Kayu Agung adalah tradisi tersebut dianggap mempunyai kesan yang sangat memberatkan jika mempelai perempuan tergolong dari keluarga yang tidak berkecukupan. Karena dalam proses tersebut adanya timbal balik dari pemberian tersebut.

Berkenaan dengan inilah dapat dikatakan bahwa tradisi dalam sebuah masyarakat budaya mempunyai suatu makna yang sangat berarti bagi mereka. Sangatlah jelas bahwa suatu kelompok atau masyarakat tidak mungkin bisa bertahan kecuali masyarakat tersebut masih mempertahankan tradisi -tradisi yang ada dalam kehidupan mereka. Karena tradisi tersebut melambangkan sebagai wadah ekspresi keagamaan, sebagai alat pengikat kelompok, dan juga sebagai benteng pertahanan kelompok. [14]

\section{Pembahasan}

Dari data hasil wawancara peneliti di lapangan pada saat observasi dengan beberapa responden, dapat dijabarkan tentang pemahaman masyarakat tentang hubungan antara tradisi ngusong $b a-$ rang dengan pembentukan keluarga sakinah Diantara responden yang mengatakan adanya hubungan

(Bandung: Citra Aditya Bakti, 2003), 12.

[14]Imam Bawani. Tradisonalisme, 34-35. 
antara tradisi dengan pembentukan keluarga sakinah yakni adanya hubungan tersebut disebabkan tradisi tersebut, ngusong barang, sebagai modal awal terbangunnya suatu keluarga yang telah dibekali beberapa perabotan rumah tangga dan pasangan suami istri tersebut tidak perlu lagi untuk membeli dan melengkapi perabotan rumah tangga mereka, oleh karena itulah dengan dibekali modal awal dalam rumah tangga bagaimana pasangan suami istri tersebut merawatnya dan menjalin hubungan yang baik dengan pasangannya.

Data jumlah katagori keluarga sakinah yang peneliti peroleh dari KUA yaitu $5631 \mathrm{kk}$ yang tergolongan pra sakinah, $22614 \mathrm{kk}$ tergolongan dalam katagori sakinah I, $8611 \mathrm{kk}$ tergolong dalam katagori sakinah II, $11860 \mathrm{kk}$ tergolong dalam katagori sakinah III, dan $7530 \mathrm{kk}$ tergolong dalam katagori sakinah III plus.[15]

Berdasarkan data yang peneliti peroleh dari KUA tentang katagori keluarga sakinah yang ada di lingkungan masyarakat setempat peneliti mencoba untuk mengetahui bagaimana pandangan masyarakat yang berpendapat adanya pengaruh tradisi ngusong barang dengan pembentukan keluarga sakinah. Dikatakan bahwa selain pengaruh tradisi ngusong barang sebagai pondasi terbentuknya suatu keluarga ada juga faktor-faktor yang mempengaruhi terbentuknya suatu keluarga yakni adanya sikap saling pengertian, sabar, saling terbuka, saling kasih sayang, dan saling toleran dalam kehidupan suami istri khususnya dalam penggunaan barang bawaan tersebut.

Selain tradisi tersebut yang mengandung makna pengikat tali hubungan suami istri sehingga pasangan suami istri harus bisa memahami peran masing - masing sehingga akan tercipta sikap saling pengertian, saling terbuka, dan toleran dalam menggunakan harta bawaan tersebut.

Keluarga merupakan unit terkecil dalam kehidupan sosial masyarakat yang terdiri dari suami istri, anak-anak serta kerabat keluarga.

[14]Imam Bawani. Tradisonalisme, 34-35.

[15]Pendataan keluarga sakinah KUA kec. Kota Kayu Agung tahun 2006.
Keluarga sebagai lembaga sosial memiliki fungsi yang dilaksanakan secara tradisional, serta keluarga dibangun atas dasar perkawinan yang sah menurut agama, hukum dan adat istiadat yang ada.

Memang tidak mudah membangun keluarga semacam ini. Banyak pengorbanan dan proses yang panjang untuk mewujudkannya. Proses ini tidak hanya terbatas pada saat telah menikah saja, tapi diawali pula dengan kesiapan tiap-tiap individu (calon suami dan calon istri) untuk mempersiapkan ilmu, ekonomi, dan mental secara baik. Tak kalah pula "ketepatan" memilih calon pendamping. Setelah menikah suami sebagai pemimpin keluarga, maupun istri atau ibu sebagai pendamping sang pemimpin harus bekerja keras mendapatkannya. Selain itu anak pun harus dilibatkan dalam memperjuangkannya[16].

Sakinah juga diartikan sebagai suatu ketenangan dan kedamaian seperti telah dilukiskan dalam $\mathrm{Al}$ Qur'an[17]

uqèd üI\%\%@!\$ tAtRr\& spoYÅ

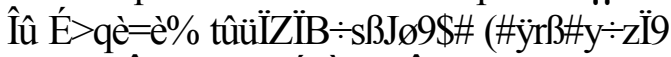
\$YZ»yĴ) yïB öNÍkÈ]»yJÎ) $3 \neg$ !ur ßqãZã

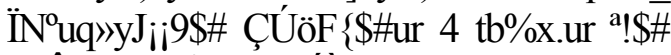
\$, Ĵ̀=tã \$VJÅ3ym Çí̇

"Dia-lah yang telah menurunkan ketenangan ke dalam hati orangorang mukmin supaya keimanan mere$k a$ bertambah di samping keimanan mereka (yang telah ada). dan kepunyaan Allah-lah tentara langit dan bumi dan adalah Allah Maha mengetahui lagi Maha Bijaksana."

Pernikahan merupakan awal terbentuknya suatu rumah tangga yang bahagia dan sakinah, walaupun pernikahan tersebut menggunakan adat istiadat yang berbeda-beda antara satu daerah dengan daerah lain. Dalam suatu program pembinaan keluarga sakinah disusun kreateria-kreteria keluarga sakinah mulai dari pra sakinah sampai kreteria sakinah III

[16]Umay M. Djakfar Shiddieq, Indahnya Keluarga Sakinah Dalam Naungan Al Qur'an dan Sunnah (Jakarta: Zakia Press, 2004), 42.

[17]QS. Al-Fath (48) : 4. 
Plus, dalam hal ini masyarakat Kayu Agung jika dilihat data yang peneliti peroleh dari KUA tentang jumlah keluarga menurut kreteria keluarga sakinah maka bisa dikatakan masyarakat Kayu Agung sudah tergolong keluarga sakinah walaupun tidak semua memenuhi kreteria sakinah III Plus akan tetapi dari jumlah kepala keluarga yang tercatat di KUA menurut kreteria sakinah hanya 5631 keluarga yang masih tergolong pra sakinah dari jumlah 56426 keluarga.[18]

Adapun penjelasan para informan tentang indikator terbentuknya keluarga sakinah dapat peneliti simpulkan bahwa rumah tangga jika dibina diatas landasan yang benar niscaya akan mampu mewujudkan berbagai tujuan. Diantara indikator terbentuknya suatu keluarga sakinah adalah ; Pertama, adanya saling pengertian antara suami istri. Diantara suami istri hendaknya saling memahami dan mengerti tentang keadaan masing-msing baik secara fisik maupun secara mental. Perlu diketahui bahwa suami istri sebagai manusia memiliki kelebihan dan kekurangan antara satu dengan yang lain, masing masing sebelumnya tidak saling mengenal, bertemu setelah sama-sama dewasa

Kedua, saling menerima kenyataan. Suami istri hendaknya sadar bahwa jodoh, rejeki, dan mati itu dalam kekuasaan Allah tidak dapat dirumuskan secara matematis. Namun kepada manusia diperintahkan untuk melakukan ikhtiar, hasilnya barulah merupakan suatu kenyataan yang harus kita terima, termasuk keadaan suami atau istri kita masing-masing dan diterima secara ikhlas.

Ketiga, saling melakukan penyesuaian diri. Penyesuaian diri dalam keluarga berarti sikap anggota keluarga berusaha untuk dapat saling mengisi kekurangan yang ada pada diri masing-masing serta mau menerima dan mengakui kelebihan yang ada pada orang lain dalam lingkungan keluarga. Kemampuan penyesuaian diri oleh masing-masing anggota keluarga mempunyai dampak yang positif bagi pembinaan keluarga maupun masyarakat dan bangsa.

[18]Pendataan keluarga sakinah KUA kec. Kota Kayu Agung tahun 2006.
Keempat, memupuk rasa cinta. Setiap pasangan suami istri mengingkan hidup bahagia. Kebahagian hidup adalah bersifat relative sesuai dengan cita rasa dan keperluannya, namun begitu setiap orang berpendapat sama bahwa kebahagian adalah segala sesuatu yang dapat mendatangkan ketentraman, keamanan, dan kedamaian, serta segala sesuatu yang berdifay pemenuhan keperluan mental spiritual manusia. Untuk dapat mencapai kebahagian keluarga hendaknya antara suami istri senantiasa memupuk rasa cinta dengan rasa saling menyayangi, kasih-mengasihi, hormat-menghormati serta saling harga-menghargai dan penuh keterbukaan.

Kelima, melaksanakan asas musyarawarah. Dalam kehidupan berkeluarga, sikap bermusyawarah terutama antara suami istri merupakan suatu yang perlu diterapkan. Hal tersebut sesuai dengan prinsip bahwa ada masalah yang tidak dapat dipecahkan selama prinsip musyawarah diamalkan. Dalam hal ini dituntut sikap terbuka, lapang dada, jujur, mau menerima dan memberi serta sikap tidak mau menang sendiri dari pihak suami maupun istri. Sikap musyawarah dalam keluarga dapat menimbilkan rasa memiliki dan rasa tanggung jawab di antara para anggota keluarga dalam menyelesaikan dan memecahkan masalah - masalah yang timbul

Keenam, saling memaafkan. Di antara suami istri harus ada sikap kesediaan untuk saling memaafkan atas kesalahan masing-masing. Hal ini penting karena tidak jarang soal yang kecil dan sepele dapat menjadi sebab terganggunya hubungan suami istri yang tidak jarang dapat menjurus kepada perselisihan yang berkepanjangan.

Pada dasarnya keluarga merupakan suatu lingkungan yang tidak hanya terdiri atas suami istri dan anak-anak yang ada didalamnya melainkan menyangkut hubungan yang lebih besar baik hubungan anggota keluarga itu sendiri maupun hubungan dengan lingkungan masyarakat yang ada di sekitar mereka sehingga tercipta suatu suasana yang aman, tentram dan damai.

\section{KESIMPULAN DAN SARAN}

\section{Kesimpulan}

Keseimbangan sebuah tradisi dalam 
perkawinan mempunyai indikasi terhadap pembentukan keluarga sakinah. Berdasarkan paparan dan diskusi yang telah dikemukakan di atas, maka peneliti dapat menarik beberapa kesimpulan sebagaimana uraian berikut

Pertama, makna tradisi ngusong barang atau ngatot san-san bagi masyarakat Kayu Agung dalam sistem perkawinan adat masyarakat Morge Siwe atau marga Kayu Agung mempunyai arti dan makna tersendiri baik secara filosofis sebagai lambang eratnya hubungan tali silaturrahim antara anggota keluarga dan juga simbol dari rasa sikap gotong royong saling membantu antara kaum kerabat jika ada pelaksanaan pernikahan. Selain itu juga tradisi tersebut mengandung makna sebagai pengikat tali hubungan suami istri dalam sebuah bangunan rumah tangga yang baru dibangun di atas mahligai perkawinan. Dengan demikian makna sebuah tradisi bagi kehidupan masyarakat sangat berarti dan tidak mungkin bisa dipisahkan diantara keduanya, tradisi mempunyai sebuah peranan penting dalam kehidupan masyarakat khususnya tradisi ngusong barang dalam adat istiadat masyarakat Kayu Agung.

Kedua, tradisi Ngusong Barang dalam sistem perkawinan adat masyarakat Kayu Agung mempunyai peranan dalam hubungannya pem-

\section{DAFTAR PUSTAKA}

Anonimos. 2003. Membina Keluarga Sakinah. Jakarta: Direktorat Jenderal Bimbingan Masyarakat Islam dan Penyelenggaraan Haji Depag.

. 2003. Petunjuk Teknis Pembinaan Gerakan Keluarga Sakinah. Jakarta: Proyek Peningkatan Kehidupan Keluarga Sakinah Ditjen Bimas Islam dan Penyelenggaraan Ibadah Haji.

Arikunto, Suharsimi. 2002. Prosedur Penelitian Suatu Pendekatan. Jakarta: Rin- bentukan sebuah keluarga sakinah dikalangan masyarakat Kayu Agung, hal ini menyakinkan bahwa terbentuknya sebuah bangunan awal keluarga tidak hanya berlandasakan sebuah bangunan ekonomi yang kuat, pendidikan, agama akan tetapi juga bangunan tersebut terbentuk dari sebuah sistem perkawinan adat yang mengunanakan tradisi yang ada seperti yang ada dikalangan masyarakat Kayu Agung, tradisi Ngusong Barang merupakan awal dari terbentuknya bangunan keluarga sakinah, karena dengan tradisi tersebut barang-barang bawaaan pada saat pernikahan sebagai modal dalam mengarungi kehidupan rumah tangga.

\section{Saran}

Kepada para pemuka adat Morge Siwe hendaknya dalam menerapkan sebuah upacara adat dengan tidak berlebihan dan selaras dengan ajaran agama.

Hendaknya untuk lebih sering mengadakan penelitian khususnya dalam segi kehidupan agama masyarakat Kayu Agung, teori tidak selamanya berjalan seiring dengan fakta lapangan termasuk dalam pembentukan sebuah keluarga sakinah.

eke Cipta.

Bawani, Imam. 1990. Tradisonalisme Dalam Pendidikan Islam. Surabaya: Al Ikhlas.

Djakfar, Umay M. 2004. Indahnya Keluarga Sakinah Dalam Naungan Al Qur'an dan Sunnah. Jakarta: Zakia Press.

Elly M. Setiady dkk. 2006. Ilmu Sosila dan Budaya Dasar. Jakarta: Kecana Prenada Media.

Endraswara, Suwardi. Metode, Teori, Teknik, Penelitian Kebudayaan: Ideologi, Epistemologi, dan Aplikasi. Sleman: Pustaka Widyatama, 2006.

Goode, William J. 2004. Sosiologi Keluar- 
ga. Jakarta: Sinar Grafika.

Hadi, Sutrisno. 2000. Metodologi Research 1. Yogyakarta: ANDI.

Hadikusuma, Hilman. 2004. Antropologi Hukum Indonesia. Bandung: Alumni. 2003. Hukum Perkawinan Adat Dengan Adat Istiadat dan Upacara adatnya. Bandung: Aditya Bakti.

Ihromi, T.O. 2006. Pokok-Pokok Antropologi Budaya. Jakarta: Yayasan Obor Indonesia.

J.Moleong, Lexy. 2001. Metodologi Penelitian Kualitatif. Bandung: Remaja Rosdakarya.

Jaih Mubarok. 2005. Modernisasi Hukum Perkawinan di Indonesia. Bandung: Pustaka Bani Quraisy.

Junaidi, Yendri. 2006. Potret Keluarga Teladan Dalam Al Qur'an. Vol. 2; Jakarta: Jurnal Kajian Islam Al Ihsan.

Junaidi,Yendri. 2006. Potret Keluarga Teladan Dalam Al Qur'an. Vol. 2; Jakarta: Jurnal Kajian Islam Al
Ihsan.

Musthofa, Agus. 2007. Poligami Yukk/ Benarkah Alqur'an Menyuruh Berpoligami Kerena Alasan Syahwat. Surabaya: Padma Press.

Narbuko, Cholid dan Abu Achmadi. 2004. Metodologi Penelitian. Jakarta: Bumi Aksara.

Nasution, S. 1998. Metode Penelitian Naturalistik Kualitatif. Bandung: Tarsito.

Nurhakim, Muhammad. 2003. Islam Tradisi dan Reformasi Pragmatis Agama dalam Pemikiran Hasan Hanafi. Malang: Bayumedia Publising.

Shihab, M. Quraish. 2007. Pengantin Al Qur'an Kalung Permata Buat Anak-anakku. Jakarta: Lentera Hati.

Subhan, Zaitunah. 2004. Membina Keluarga Sakinah. Bantul: Pustaka Pesantren.

Sunggono, Bambang. 2005. Metodologi Penelitian Hukum. Jakarta: PT Raja Grafindo Persada.

Thohir, Asrofi, M. 2006. Keluarga Sakinah Dalam Islam Jawa. Yogyakarta: Arindo Nusa Media. 